\title{
Assessment of the technical state and the possibility of its control for the further safe operation of building structures of mining facilities
}

\author{
Yurii Otrosh $^{1 *}$, Yevhen Rybka ${ }^{1}$, Oleksandr Danilin ${ }^{1}$, and Maksym Zhuravskyi ${ }^{1}$ \\ ${ }^{1}$ National University of Civil Defence of Ukraine, 94 Chernyshevska St., 61023 Kharkiv, Ukraine
}

\begin{abstract}
There are about 200 operating mines in Ukraine, most of which have not been reconstructed for more than 20 years. Modern anthropogenic and ecological impacts are caused by local technogenic catastrophes and the global ecological crisis. The statistical data on the safety of Ukrainian mines were considered. A literary analysis has been made of advanced expertise in the technical state assessment of the building structures. The purpose of the study is to make optimal decisions when constructing, operating and maintaining the buildings. The procedure for assessing the building state is the result of research, the purpose of which is to develop a technique for reliable and operational assessment of the building structures technical state. In this paper, a technique is proposed for inspecting the constructions and assessing their technical state. The maximum efforts in elements of the adapted frame were used for checking calculations and constructional design. The obtained calculation results were used in determining the sufficiency of existing cross section value of the structure elements. According to the calculation results, a conclusion has been made that hardness, stability and rigidity of the frame elements as a whole are ensured; further operation of the building structures is possible providing for the project development to strengthen building structures and to implement the design solutions at the construction site. In order to ensure the continued normal operation, it is necessary to develop a project for strengthening the structures, as well as a project for fire protection of building structures.
\end{abstract}

\section{Introduction}

Ukraine is the first in Europe and the eighth in the world in terms of geological reserves of fossil coal. The explored coal reserves of Ukraine amount to about 50 billion tons. The undiscovered reserves - about 120 billion tons. The structure of balance reserves includes all grades from brown coal to highly metamorphosed anthracite coal.

Mine method of coal mining is very dangerous. There are collapses and explosions of natural gas in the mines. By the number of mine accidents, Ukraine is second only to China

\footnotetext{
* Corresponding author: yuriyotrosh@gmail.com
} 
in the world.

There are about 200 operating mines in Ukraine, most of which have not been reconstructed for more than 20 years and require changes in the ventilation equipment.

Modern anthropogenic impact and ecological damage, conditioned by local technogenic catastrophes [1,2] and the global ecological crisis, evidence that the current ecosystems state constitutes a significant threat to all mankind [3 - 5].

The causes of accidents in the mines:

- methane explosion;

- coal dust explosion;

- fire;

- collapses.

Risk factors for injuries in the explosion at the mine:

- powerful shock wave that spreads through the mine workings and causes considerable destructions;

- high temperature flame, which leads to fires;

- high concentration of poisonous gases;

- collapses.

The safety of Ukrainian mines: $90 \%$ of mines are gas hazardous; $30 \%$ of mines are dangerous because of sudden emissions of coal, rock, gas; $70 \%$ of mines are hazardous due to explosions of coal emissions; $30 \%$ of mines are hazardous due to spontaneous combustion of coal $[6,7]$.

Also recently in Ukraine, there have been frequent cases of collapse, destruction of buildings and structures as a result of unreliable work or failure of building structures and systems as a whole, leading to the occurrence of fires. The number of fires in Ukraine, occurred in buildings and structures, made up 53\% of the total number, and the death toll in them was about $96 \%$.

During the period from 2007 to 2018, at an average, 34752 fires occurred in buildings and structures, from which 2546 people died, 1346 people were injured. For a certain period, at an average, 22353 buildings and structures for various purposes were destroyed or damaged, of which 4281 buildings were completely destroyed.

According to statistical data for 2018, 43.2\% $(33,949)$ of all fires in Ukraine occurred in buildings and structures; 5.5\% (4 346) - in transport; 47.6\% (37 451) occurred in the open space of materials storage, open areas, external installations and the like; 3.7\% (2 862) occurred on other objects that are not included into the list.

The work [8] summed up the engineering assessment study of the degree of thermal damage to reinforced concrete structures. The fire arose in the area of the reinforced concrete structure and significantly damaged the bearing external foundation wall. The purpose of assessment was to quickly assess the technical state of the wall and to recommend the necessary variants for repairing or replacing. The engineering assessment of damaged wall included a phase of non-destructive evaluation consisting of ultrasonic testing a pulse velocity and laboratory testing of concrete samples extracted from the damaged wall. The results of non-destructive and laboratory evaluation have shown that the concrete fracture zones are edged by the near-surface layer. The recommendations for repairing were based on the removal and replacement of damaged concrete sections specified by the test program.

In the thesis [9], in order to determine the mechanical behavior of reinforced concrete columns in the case of a fire, it is proposed to apply simplified methods as well as the table values given in EN 1992-1-2 (2004). From the point of view of safety and efficiency, the table values represented in Eurocode 2 (2004) should be revised, and the existing simplified methods for designing the reinforced concrete columns at ambient temperature should be adapted for use in the conditions of high temperatures. 
The assessment of the existing buildings state with the use of non-destructive testing method is studied in [10]. The continuous monitoring of reinforced concrete structures using the appropriate methods and available methods of reconstruction contributes to a significant decrease in the responding speed of concrete structures, thereby increasing the service life of structures. The non-destructive testing methods $[11,12]$ have a greater advantage in assessing the uniformity, durability, degree of reinforcement corrosion in concrete, etc. for damaged structures.

In the work [13], a review is represented of the principles and practices of assessing the state of existing reinforced concrete structures, as well as a technique of work to assess the technical state before repairing, from the point of view of an expert. The non-destructive testing methods, methods for experimental research into materials, the choice of samples and the development of assessment variants are also considered.

To assess the technical state of buildings and their structures, the methods of risk analysis can be used. These methods can be used for pricing the construction according to the state, age and use. The method of assessing the universal matrix of the risks analysis is applied in the work [14].

The purpose of the study [15] is to provide the parties involved in the construction industry with some key performance indicators that can help them in optimal decisionmaking in the construction, operation, maintenance and repair of the building. The procedure for assessing the state of a building is a result of the original study, the purpose of which was to develop a technique for reliable, but quick assessment of the assets state, which should be made before they are acquired or the main decisions on their reconstruction are made.

\section{Formulation of a problem}

The cost of coal, the reliable and safe operation of coal mines are largely determined by the stability of mine workings [16 - 18]. The mine fastening is the most important factor to ensure it, and, at the same time, the fastening of mine workings is the most difficult and labour intensive process in the technology of mining operations. The steel frame fastening, which is a combination of separately located frames and interframe fencing (laggings), is the most widespread in the coal industry.

The laggings are an important lifting and distribution element of the mine fastening. It is recommended to set metal laggings with anti-corrosion coating in mine workings with a long service life. To ensure the mine working stability in difficult mining and geological environment, plate (laminar) laggings of steel sheet with a thickness of $2-3 \mathrm{~mm}$ are used. In order to create a strong structure that operates in a pliable mode, a lagging of thin steel sheet has been developed, made in the form of a spatial thin-walled element in the form of a groove with the hooks on the ends.

Until now, the mechanism of laggings interaction with a rock massif has not been studied thoroughly, there are no reasonable recommendations for their designing, and areas for the rational use of interframe fencing in various mining and geological conditions are not defined.

A significant influence on the state of interframe fencing has an aggressive mine environment due to the presence of a large amount of moisture and gases.

The corrosion of metal worsens the state and restricts the service life of steel lattice and sheet structures, since the destruction rate of the metal surface layer in mine environments reaches up to $0.1-0.2 \mathrm{~mm}$ per year, which requires effective corrosion protection.

Thus, it can be concluded that in the coal industry, wooden and reinforced concrete laggings do not correspond to the operation mode of steel fastening in terms of their loadbearing capacity and durability (wooden laggings), therefore, they do not ensure safe operation of mine workings. The universally accepted practice of applying the same type of 
lagging along the entire frame perimeter does not correspond to the principle of optimal designing and leads to excess consumption of material resources.

As it can be seen from the above analysis, the issues of technical regulation of both building structures and the building as a whole in order to avoid mistakes during the inspection, evaluation of the technical state of building structures and restoration of the serviceability of existing structures, as well as predicting the technical state and possible destruction after exposure to high temperatures (fires), is an actual scientific and technical problem, the solution of which will positively affect the main indicators of fire statistics (deaths and injuries of people, the number of fires, fire damage, the average duration of localization and liquidation of fires).

In this paper, a technique is described for inspecting the constructions and assessing their technical state. Inspection of structures and assessing their technical state is proposed to conduct in the following sequence:

- analysis of the data contained in the provided design documents;

- on-site visual and instrumental inspecting the bearing structures of a building, identification and photographing of defects and damages;

- performing the necessary calculations of structures;

- preparing the conclusion about the technical state of bearing structures before repairing.

\section{A technique of determining the technical state}

As an object for inspecting the technical state, it has been chosen a building used for the needs of mining industry.

According to the tasks set, the following works have been carried out:

- familiarization with the object under study;

- visual and instrumental structures inspecting;

- measurment works with the development of measurment drawings;

- performing the necessary calculations of structures with account of the inspection results of building structures with further development of recommendations for the weatherization of the wall cladding and roof of the building;

- assessing the technical state of structures based on the results of visual and instrumental inspection;

- preparing the conclusion about the technical state of structures;

- developing the technical documents under the necessity for repair and the weatherization of the wall cladding and roof, as well as recommendations for ensuring the long and reliable structures operation.

When performing the work of structures inspection, the following instruments and devices were used:

- a laser rangefinder Sturm DL1040 to measure dimensions;

- camera OLYMPUS SP-510UZ;

- a metal measuring reel according to GOST 7502.

The object has been analyzed according to the first point of a technique. Thus, by the plan, the building is a rectangular one-story structure with a steel framework, built in the 70 s of the last century. There are no building documents.

The structural system of the building is skeletonized. The columns with built-up cross section are made of steel channels No. 20. The total dimensions of the columns cross section $-200 \times 400 \mathrm{~mm}$. The roof of the building is made of rolled sections. The steel arches are used as the bearing elements of the roof, and the girders are rested on their upper belts (Fig. 1).

The columns are connected to separate reinforced concrete foundations with the help of roof bolts. The wall cladding and coating are made of steel sheets. 
The spatial rigidity of the building structures is ensured by the joint work of columns, trusses, a system of vertical ties along the columns, horizontal struts along the columns, spans and a system of horizontal and vertical ties rigidly connected with the foundations (Fig. 1).
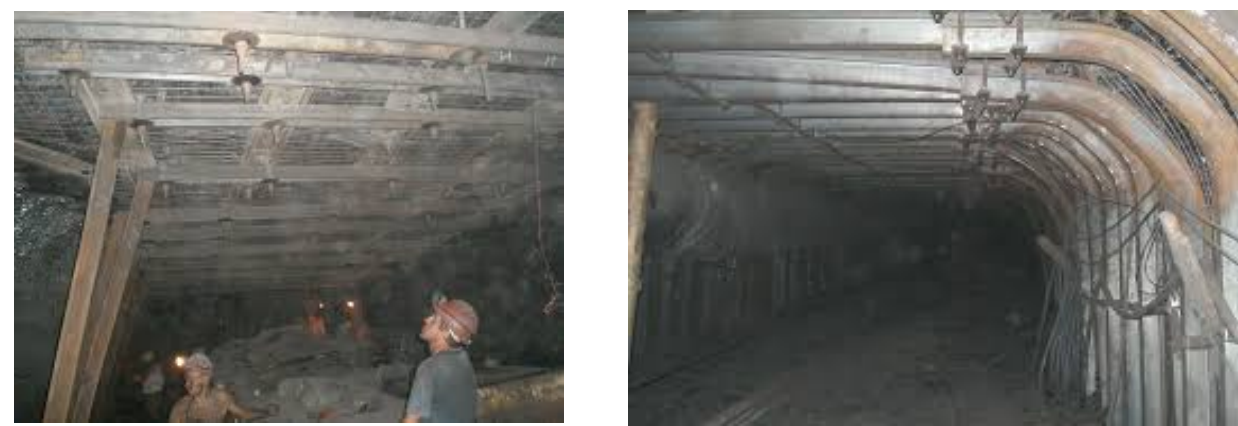

Fig. 1. View of bearing structures of the building.

According to the second point of a technique, it has been performed a visual and instrumental inspection of the structures, as well as the measurment works with the development of measurment drawings.

When inspecting, individual defects and damage have been revealed:

- destruction of a protective anti-corrosion coating on certain parts of structures;

- connection of the elements of ties and struts with columns is made with deviations from typical design solutions;

- the lack of the protective cladding of steel structures;

- the absence of bolts in connections, counter nuts or other measures against the selfunscrewing of nuts in the area of bolted connections;

- lack of horizontal ties in the coating in the axes 1-2, 8-9;

- lack of vertical ties in the coating in the axes 1-2, 8-9.

According to the third point of a technique, necessary calculations have been made with account of the inspection results of the building structures. The load on the structures was adopted according to DBN V. 1.2-2:2006 [19].

The criticality-based safety factor $\gamma_{n}=1.1$, when calculating the structures, is accepted depending on the class of consequences (responsibility) of the object and the category of responsibility of structures by the Table 5 DBN V. 1.2-14-2018 [20]. The class of consequences (responsibility) of the structure is accepted as CC2 according to the Table 1 DSTU-N B V.1.2-16: 2013 [21].

There are no more than 50 people permanently at the facility (filled at least 8 hours a day for not less than 150 days a year), which corresponds to the $\mathrm{CC} 1$ class. From time to time there are up to 100 people, which corresponds to the $\mathrm{CC} 1$ class. Outside the facility, danger is possible for a number of people up to 100 , which corresponds to the CC1 class. The volume of potential economic damage from 2000 to 150000 minimum wage that corresponds to the CC2 class. An object of local significance can be lost (the object does not have the status of a national monument and has no national significance), therefore the CC2 hazard class. The stopping of functioning the facilities of transportation lines, communications, energy and other engineering networks - is local, which corresponds to the $\mathrm{CC} 2$ class. Therefore, $\mathrm{CC} 2$ is the maximum class of consequences by all criteria. The object complexity category - III (Table A.1 of annex A [22]).

The design diagram of bearing structures was adopted in the form of a frame (Fig. 2). The load from the wind pressure and from own weight of the structures is applied in the form of a uniformly distributed load along the length of the sections into which the frame 
was conventionally divided. The load from the production equipment weight is applied in the form of concentrated forces in the places of setting the equipment.

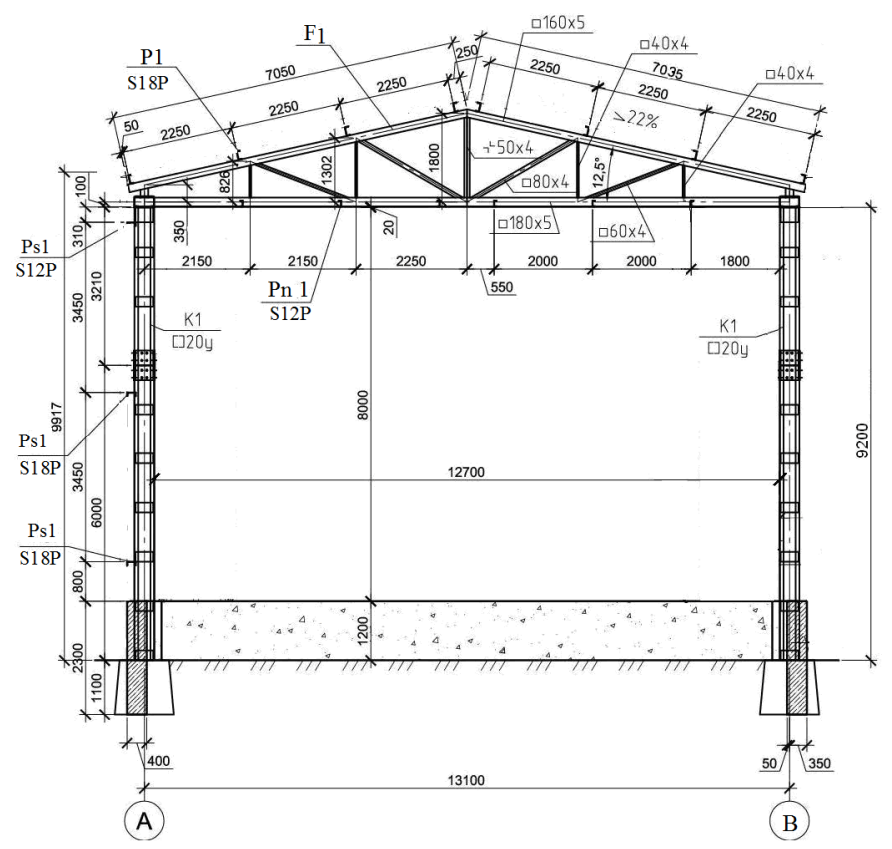

Fig. 2. Section drawing 1-1.

The obtained maximum efforts in the elements of the adapted frame were used for checking calculations and constructional design. The obtained calculation results were used in determining the sufficiency of existing cross section value of the structure elements. The results of checking calculations are represented in Fig. 3.

According to the calculation results, the following conclusions have been made:

- hardness, stability and rigidity of the frame elements as a whole are ensured. It is required to set additional elements to increase rigidity;

- further operation of the building structure is possible providing for the project development to strengthen building structures and to implement the strengthening at the construction site;

- on the basis of the calculations made, it is necessary to develop projects for repairing the building structures.

According to the fourth point of a technique, the general conclusions have been prepared on the technical state of the bearing structures in connection with the repair, and possibly with the use of protective cladding to increase the degree of fire resistance of such structures.

The obtained calculation results were used in determining the sufficiency of existing cross section value of the structure elements.

Checking calculations were performed using the Lir-STK calculated complex. The sufficiency of existing cross sections of the structure elements has been determined.

The results of the calculations are represented in Table 1. 
$a$

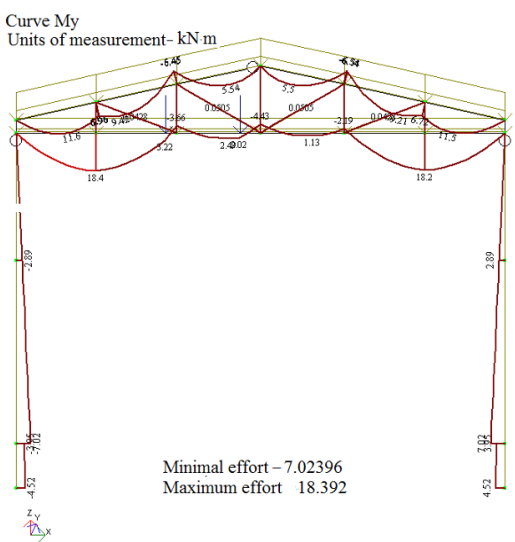

$b$

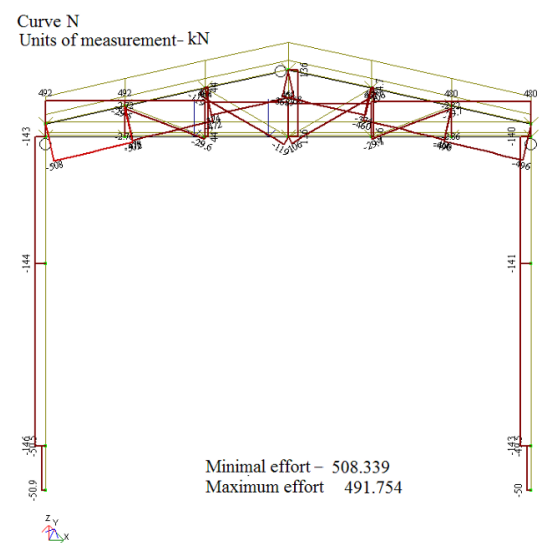

Fig. 3. Diagrams of bending moments (a) and axial forces (b) under loading 1 .
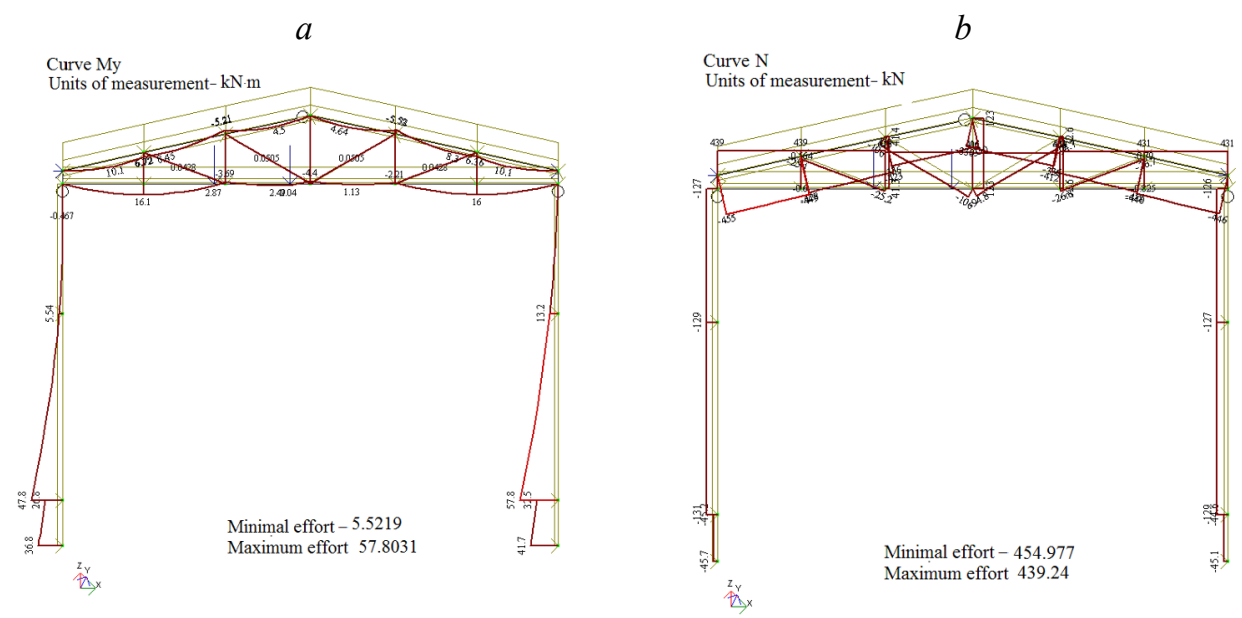

Fig. 4. Diagrams of bending moments (a) and axial forces (b) under loading 4 .

$a$

Curve My
Units of measurement- $\mathrm{kN} \cdot \mathrm{m}$

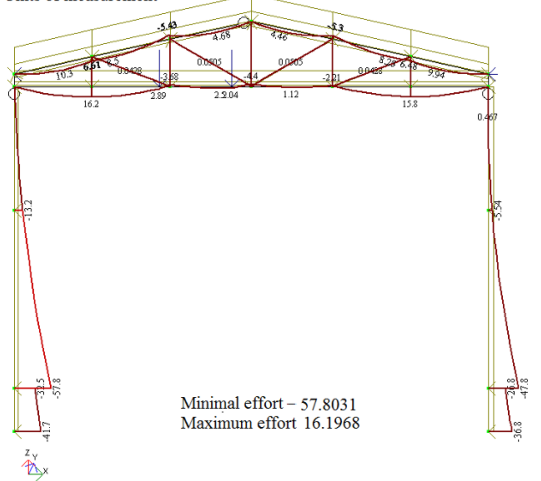

$b$

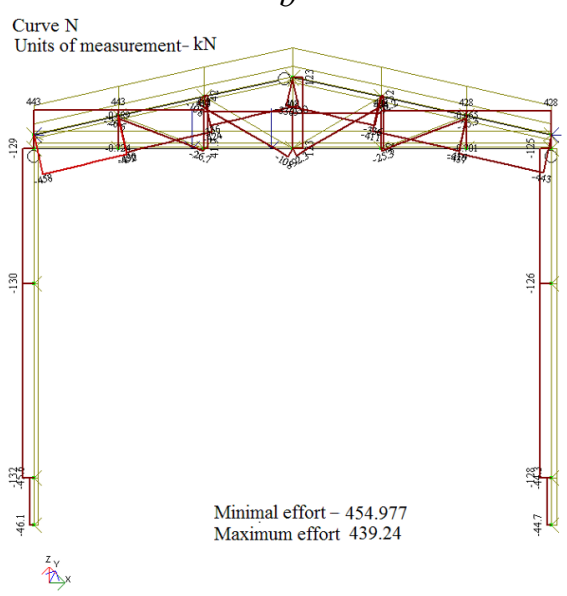

Fig. 5. Diagrams of bending moments (a) and axial forces (b) under loading 5. 
Table 1. The results of checking calculations of the column elements.

\begin{tabular}{|c|c|c|c|c|c|c|c|c|c|c|c|c|c|c|c|}
\hline \multirow{2}{*}{ Element } & \multirow{2}{*}{ NS } & \multirow{2}{*}{ Group } & \multirow{2}{*}{$\begin{array}{c}\text { Lattice } \\
\text { spacing } \\
\text { (fins), } \\
\text { m }\end{array}$} & \multicolumn{11}{|c|}{$\begin{array}{l}\text { The exhaustion percentage of the bearing capacity } \\
\text { of the column by cross sections, } \%\end{array}$} & \multirow{2}{*}{$\begin{array}{c}\text { Element } \\
\text { length, } \\
\mathrm{m}\end{array}$} \\
\hline & & & & nor & UY1 & $\mathrm{UZ1}$ & UYZ & GY1 & GZ1 & US & UP & 1PS & 2PS & M.U & \\
\hline \multicolumn{16}{|c|}{ Cross section: 2. Section Molodechno $150 \times 4$} \\
\hline \multicolumn{16}{|c|}{ Section: $150 \times 4$; GOST $30245-2003$} \\
\hline \multicolumn{16}{|c|}{ Steel: C245; GOST 27772-88 } \\
\hline \multirow{2}{*}{\multicolumn{16}{|c|}{\begin{tabular}{l|l}
\multicolumn{2}{l}{ Assortment: steel roll-formed closed square sections for building structures } \\
UK22
\end{tabular}}} \\
\hline & & & \multicolumn{13}{|c|}{$\begin{array}{c}\text { Selected:2. Section Molodechno } 180 \times 5 \\
\end{array}$} \\
\hline & & & \multirow{2}{*}{\multicolumn{13}{|c|}{$\begin{array}{l}\text { Section: } 180 \times 5 \text {; GOST } 30245-2003 \\
\text { Steel: C245; GOST } 27772-88\end{array}$}} \\
\hline & & & & & & & & & & & & & & & \\
\hline 13 & 1 & UK22 & 0.00 & 59 & 0 & 0 & 0 & 7 & 7 & 68 & 0 & 59 & 7 & 68 & 2.15 \\
\hline 13 & 2 & UK22 & 0.00 & 98 & 0 & 0 & 0 & 7 & 7 & 62 & 0 & 98 & 7 & 62 & 2.15 \\
\hline 14 & 1 & UK22 & 0.00 & 98 & 0 & 0 & 0 & 7 & 7 & 62 & 0 & 98 & 7 & 62 & 2.15 \\
\hline 14 & 2 & UK22 & 0.00 & 67 & 0 & 0 & 0 & 7 & 7 & 66 & 0 & 67 & 7 & 66 & 2.15 \\
\hline 15 & 1 & UK22 & 0.00 & 64 & 0 & 0 & 0 & 7 & 7 & 66 & 0 & 64 & 7 & 66 & 2.25 \\
\hline 15 & 2 & UK22 & 0.00 & 65 & 0 & 0 & 0 & 7 & 7 & 66 & 0 & 65 & 7 & 66 & 2.25 \\
\hline 16 & 1 & UK22 & 0.00 & 64 & 0 & 0 & 0 & 7 & 7 & 66 & 0 & 64 & 7 & 66 & 2.25 \\
\hline 16 & 2 & UK22 & 0.00 & 59 & 0 & 0 & 0 & 7 & 7 & 67 & 0 & 59 & 7 & 67 & 2.25 \\
\hline 17 & 1 & UK22 & 0.00 & 62 & 0 & 0 & 0 & 7 & 7 & 67 & 0 & 62 & 7 & 67 & 2.15 \\
\hline 17 & 2 & UK22 & 0.00 & 96 & 0 & 0 & 0 & 7 & 7 & 62 & 0 & 96 & 7 & 62 & 2.15 \\
\hline 18 & 1 & UK22 & 0.00 & 96 & 0 & 0 & 0 & 7 & 7 & 62 & 0 & 96 & 7 & 62 & 2.15 \\
\hline 18 & 2 & UK22 & 0.00 & 58 & 0 & 0 & 0 & 7 & 7 & 68 & 0 & 58 & 7 & 68 & 2.15 \\
\hline \multicolumn{16}{|c|}{ Cross section: 3 . Section Molodechno $120 \times 5$} \\
\hline \multicolumn{16}{|c|}{ Section: $120 \times 5$; GOST 30245-2003 } \\
\hline \multirow{2}{*}{\multicolumn{16}{|c|}{ Steel: C245; GOST 27772-88 }} \\
\hline \multirow{2}{*}{\multicolumn{3}{|c|}{$\begin{array}{r}\text { roll-formed closed square sections for building structures } \\
\text { Selected: } 3 \text {. Section Molodechno } 160 \times 4.5\end{array}$}} & & & & & & & & & & & & & \\
\hline & & & \multicolumn{13}{|c|}{ Selected: 3. Section Molodechno $160 \times 4.5$} \\
\hline & & & \multicolumn{13}{|c|}{ Section: $160 \times 4.5$; GOST $30245-2003$} \\
\hline & & & & & & & Steel: & $\mathrm{C} 245$ & ; GOS & T 277 & $72-88$ & & & & \\
\hline 23 & 1 & UK12 & 0.00 & 76 & 80 & 80 & 0 & 27 & 27 & 72 & 72 & 80 & 27 & 72 & 2.20 \\
\hline 23 & 2 & UK12 & 0.00 & 97 & 93 & 92 & 0 & 29 & 29 & 74 & 74 & 97 & 29 & 74 & 2.20 \\
\hline 24 & 1 & UK12 & 0.00 & 93 & 90 & 88 & 0 & 28 & 28 & 72 & 72 & 93 & 28 & 72 & 2.20 \\
\hline 24 & 2 & UK12 & 0.00 & 90 & 87 & 86 & 0 & 28 & 28 & 71 & 71 & 90 & 28 & 71 & 2.20 \\
\hline 25 & 1 & UK12 & 0.00 & 75 & 72 & 71 & 0 & 26 & 26 & 64 & 65 & 75 & 26 & 65 & 2.30 \\
\hline 25 & 2 & UK12 & 0.00 & 55 & 58 & 58 & 0 & 24 & 24 & 65 & 65 & 58 & 24 & 65 & 2.30 \\
\hline 27 & 1 & UK12 & 0.00 & 74 & 78 & 78 & 0 & 27 & 27 & 72 & 72 & 78 & 27 & 72 & 2.20 \\
\hline 27 & 2 & UK12 & 0.00 & 94 & 91 & 90 & 0 & 28 & 28 & 73 & 73 & 94 & 28 & 73 & 2.20 \\
\hline 28 & 1 & UK12 & 0.00 & 90 & 87 & 86 & 0 & 28 & 28 & 71 & 71 & 90 & 28 & 71 & 2.20 \\
\hline 28 & 2 & UK12 & 0.00 & 88 & 86 & 84 & 0 & 28 & 28 & 71 & 71 & 88 & 28 & 71 & 2.20 \\
\hline 29 & 1 & UK12 & 0.00 & 76 & 72 & 71 & 0 & 26 & 26 & 64 & 65 & 76 & 26 & 65 & 2.30 \\
\hline 29 & 2 & UK12 & 0.00 & 55 & 58 & 58 & 0 & 24 & 24 & 65 & 65 & 58 & 24 & 65 & 2.30 \\
\hline
\end{tabular}

\section{Conclusions}

Recently in Ukraine, there have been frequent cases of collapse, destruction of buildings and structures, including in the mining industry, as a result of unreliable work or failure of building structures and systems as a whole, leading to the occurrence of fires. In this regard, in this paper, a technique is proposed for assessing the technical state of building structures of the mining industry.

A structure, which belongs to the mining industry, was built in the 70 s of the last century. There are no any design and enforcement documents for a building. When inspecting the structures, it has been determined their technical state. The technical state of the building structures was conducted by means of a visual and instrumental inspection with photographic evidence of defects and damage. 
According to the calculation results, the following conclusions have been made: hardness, stability and rigidity of the frame elements as a whole are ensured. In accordance with the requirements of European standards (mechanical resistance, stability and fire safety) for buildings of the mining industry, further operation of the building structures is possible providing for the project development to repair building structures and to implement the design solutions at the construction site. In compliance with the requirements of current regulatory documents [19], the technical state of existing structures is considered as unserviceable for normal operation.

In order to ensure the continued normal operation, it is necessary to develop a project for strengthening structures, as well as a project for fire protection of building structures, as well as repair the bearing structures according to the developed project. When reconstructing, to provide the repair of existing bearing structures of the framework (columns and coatings) with the replacement of separate elements and by setting additional ties.

Authors express their gratitude to O.I. Holodnov, Doctor of Technical Sciences, Professor, Head of Department of OJSC V. Shymanovskyi Ukraininan Research and Design Institute of Steel Construction for the help and consultations in performing this work.

\section{References}

1. Semko A. N., Beskrovnaya M. V., Vinogradov S. A., Hritsina I. N., Yagudina N. I. (2014). The usage of high speed impulse liquid jets for putting out gas blowouts. Journal of Theoretical and Applied Mechanics, 52(3), 655-664.

2. Dubinin, D., Korytchenko, K., Lisnyak, A., Hrytsyna, I., \& Trigub, V. (2017). Numerical simulation of the creation of a fire fighting barrier using an explosion of a combustible charge. Eastern-European Journal of Enterprise Technologies, 6(10(90)), 11-16. https://doi.org/10.15587/1729-4061.2017.114504

3. Vasiliev, M.I., Movchan, I.O., \& Koval, O.M. (2014). Diminishing of ecological risk via optimization of fire-extinguishing system projects in timber-yards. Naukovyi Visnyk Natsionalnoho Hirnychoho Universytetu, (5), 106-113.

4. Andronov, V.A., Danchenko, Yu.M., Skripinets, A.V., \& Bukhman, O.M. (2014). Efficiency of utilization of vibration-absorbing polimer coating for reducing local vibration Terms and conditions Privacy policy. Naukovyi Visnyk Natsionalnoho Hirnychoho Universytetu, (6), 85-91.

5. Vambol, S., Vambol, V., Kondratenko, O., Suchikova, Y., \& Hurenko, O. (2017). Assessment of improvement of ecological safety of power plants by arranging the system of pollutant neutralization. Eastern-European Journal of Enterprise Technologies, 3(10(87)), 63-73. https://doi.org/10.15587/1729-4061.2017.102314

6. Tiutiunyk, V.V., Ivanets, H.V., Tolkunov, I.A., \& Stetsyuk, E.I. (2018). System approach for readiness assessment units of civil defense to actions at emergency situations. Naukovyi Visnyk Natsionalnoho Hirnychoho Universytetu, (1), 99-105. https://doi.org/10.29202/nvngu/2018-1/7

7. Rybalova, O., \& Artemiev, S. (2017). Development of a procedure for assessing the environmental risk of the surface water status deterioration. Eastern-European Journal of Enterprise Technologies, 5(10(89)), 67-76. https://doi.org/10.15587/1729-4061.2017.112211

8. Dilek Dilek, U. (2007). Assessment of Fire Damage to a Reinforced Concrete Structure during Construction. Journal of Performance of Constructed Facilities, 21(4), 257-263. https://doi.org/10.1061/(asce)0887-3828(2007)21:4(257)

9. Wang, Lijie. (2017). Second-order effects in reinforced concrete columns exposed to fire. Universiteit Gent.

10. Venkatesh, P., \& Alapati, M. (2017). Condition Assessment of Existing Concrete Building Using Non-Destructive Testing Methods for Effective Repair and Restoration-A Case Study. Civil Engineering Journal, 3(10), 841. https://doi.org/10.28991/cej-030919 
11. Andronov, V., Pospelov, B., \& Rybka, E. (2016). Increase of accuracy of definition of temperature by sensors of fire alarms in real conditions of fire on objects. Eastern-European Journal of Enterprise Technologies, 4(5(82)), 38. https://doi.org/10.15587/1729-4061.2016.75063

12. Andronov, V., Pospelov, B., Rybka, E., \& Skliarov, S. (2017). Examining the learning fire detectors under real conditions of application. Eastern-European Journal of Enterprise Technologies, 3(9(87)), 53-59. https://doi.org/10.15587/1729-4061.2017.101985

13. Dilek, U. (2009). Condition assessment of concrete structures. Failure, Distress and Repair of Concrete Structures, 84-137. https://doi.org/10.1533/9781845697037.1.84

14. Bilanič, M. et al. (2014). Application of Risk Analysis for Building Evaluation. Advanced Materials Research, (1020), 879-882.

15. Dejaco, M. C., Re Cecconi, F., \& Maltese, S. (2017). Key Performance Indicators for Building Condition Assessment. Journal of Building Engineering, (9), 17-28. https://doi.org/10.1016/j.jobe.2016.11.004

16. Bondarenko, V., Kovalevs'ka, I., \& Fomychov, V. (2012). Features of carrying out experiment using finite-element method at multivariate calculation of "mine massif - Combined support" system. Geomechanical Processes during Underground Mining: School of Underground Mining 2012, 7-13. https://doi.org/10.1201/b13157-3

17. Kovalevs'ka, I., Symanovych, G., \& Fomychov, V. (2013). Research of stress-strain state of cracked coal-containing massif near-the-working area using finite elements technique. Annual Scientific-Technical Collection - Mining of Mineral Deposits 2013, 159-163. https://doi.org/10.1201/b16354-28

18. Bondarenko, V., Kovalevs'ka, I., Ganushevych, K. (2014). Progressive technologies of coal, coalbed methane, and ores mining. (2014). Progressive Technologies of Coal, Coalbed Methane, and Ores Mining. https://doi.org/10.1201/b17547

19. DBN V.1.2-2:2006. (2006). Systema zabezpechennia nadiinosti ta bezpeky budivelnykh obiektiv. Navantazhennia i vplyvy. Normy proektuvannia. Kyiv: Minbud Ukrainy.

20. DBN V.1.2-14-2018. (2018). Systema zabezpechennia nadiinosti ta bezpeky budivelnykh obiektiv. Zahalni pryntsypy zabezpechennia nadiinosti ta konstruktyvnoi bezpeky budivel, sporud, budivelnykh konstruktsii ta osnov. Kyiv: Minrehionbud Ukrainy.

21. DSTU-N B V.1.2-16:2013. (2013). Vyznachennia klasu naslidkiv (vidpovidalnosti) ta katehorii skladnosti obiektiv budivnytstva. Kyiv: Minrehionbud Ukrainy.

22. DSTU B V.2.6-210:2016. (2016). Otsinka tekhnichnoho stanu stalevykh budivelnykh konstruktsii, shcho ekspluatuiutsia. Kyiv: Minrehionbud Ukrainy. 